\title{
CANDIDA IN SALIVA OF BRAZILIAN HEMOPHILIC PATIENTS
}

\author{
CANDIDA NA SALIVA DE PACIENTES HEMOFÍLICOS BRASILEIROS
}

\author{
Claudio Maranhão PEREIRA, Fábio Ramôa PIRES¹, Maria Elvira Pizzigatti CORRÊA², \\ Osvaldo DI HIPÓLITO JÚNIOR ${ }^{3}$, Oslei Paes de ALMEIDA ${ }^{4}$
}

\begin{abstract}
1- DDS, PhD, Oral Pathology, Piracicaba Dental School, State University of Campinas (UNICAMP), Piracicaba/SP, Brazil.
2- DDS, MSc, Dentistry Service, Center of Hematology and Hemotherapy (HEMOCENTRO), State University of Campinas (UNICAMP), Campinas SP, BRAZIL.

3- DDS, PhD, Associate Professor, Semiology, Piracicaba Dental School, State University of Campinas (UNICAMP), Piracicaba/SP, Brazil.

4- DDS, PhD, Oral Pathology, Piracicaba Dental School, State University of Campinas (UNICAMP), Piracicaba/SP, Brazil.

Corresponding address: Claudio Maranhão Pereira - Faculdade de Odontologia de Piracicaba - UNICAMP - Patologia Oral - Diagnóstico Oral r. 12, 255, ap. 101, Centro, Goiânia-GO - CEP: 74015-040 - Phone: (19) 3412-5213 - Email: claudiomaranhao@hotmail.com
\end{abstract}

Received: February 13, 2004 - Returned for modification: April 19, 2004 - Accepted: May 19, 2004

\begin{abstract}
$H$

emophilia is a common hereditary hemorrhagic disorder, however little is known about the oral microflora of hemophilic patients. The aim of this study was to quantify the Candida and identify its species in non-stimulated saliva of hemophilic patients, and consider its relationship with clinical factors influencing Candida carriage. This study comprised evaluation of 86 hemophilic patients of the Hematology Center/UNICAMP and 43 healthy subjects as controls. All patients were submitted to anamnesis, intraoral examination and unstimulated saliva collection. Candida counts and species identification were performed in salivary samples. Candida was present in $64 \%$ of the hemophilic patients and in $44 \%$ of the healthy controls. C. albicans represented $65 \%$ and $68 \%$ of the isolated species, in hemophiliacs and control group respectively, and C. tropicalis was the second most common species in both groups. These results indicate that hemophilic patients carry Candida more frequently and in higher counts than healthy controls, independently of oral clinical parameter considered, as viral infections, complete dentures, transfusions of hemoderivatives, and salivary flow.
\end{abstract}

Uniterms: Candida; Hemophiliacs; Candidosis; Hemophilia; Candida tropicalis.

\section{RESUMO}

$H$ emofilia é uma alteração hemorrágica hereditária comum, entretanto pouco se sabe a respeito da microbiota oral destes indivíduos. O objetivo deste estudo foi quantificar a presença de Candida e identificar as suas espécies na saliva de hemofílicos, correlacionando os resultados com fatores clínicos que possam influenciar a presença deste fungo. Foram avaliados 86 hemofílicos do Hemocentro/UNICAMP e 43 indivíduos saudáveis. Todos os pacientes foram submetidos a anamnese, exame clínico intra-oral e coleta de saliva de forma não estimulada. A quantificação e identificação das espécies de Candida foram realizadas nas amostras de saliva. Candida estava presente em $64 \%$ dos hemofílicos e em $44 \%$ dos indivíduos saudáveis. C. albicans representou $65 \%$ e $68 \%$ das espécies identificadas, nos hemofílicos e grupo controle respectivamente, e $C$. tropicalis foi a segunda espécie mais comum. Estes resultados sugerem que pacientes hemofílicos albergam mais freqüentemente Candida na cavidade bucal e em maiores quantidades que os indivíduos do grupo controle, independentemente dos parâmetros clínicos analisados, como infecção viral, próteses dentárias, transfusões de hemoderivados e fluxo salivar.

Unitermos: Candida; Hemofílicos; Candidose; Hemofilia.

\section{INTRODUCTION}

Hemophilia is a hemorrhagic disorder caused by hereditary deficiency of factor VIII or IX, characterizing hemophilia A and B, respectively ${ }^{2,5,14}$. Hemophilia A is caused by reduction of the serum level or activity of factor VIII, an important protein in the activation of factor $\mathrm{X}$ in the blood clotting sequence. The disease shows an $\mathrm{X}$-linked recessive pattern, affecting predominantly males. According to factor VIII activity detected in blood, hemophilia is classified in 
mild (6 to $30 \%$ of activity), moderate (2 to $5 \%$ ) and severe (less than 1\%). Hemorrhagic episodes are related to the severity of the disease, although all patients can suffer hemorrhage following trauma or surgical procedures ${ }^{2,5,13}$. Hemophilia B is characterized by deficiency of factor IX with its pattern of transmission and clinical characteristics similar to hemophilia $\mathrm{A}^{13}$.

Candida species have been found in the oral cavity of 25 to $50 \%$ of healthy subjects ${ }^{1,12}$. C. albicans is the most common, representing 60 to $90 \%$ of the isolated species ${ }^{9,29}$. Local and systemic factors can modify Candida carriage in the mouth as patients' age and gender, complete dentures, smoking, xerostomia, diabetes, drugs and genetic or acquired immunological deficiency ${ }^{12,19}$.

Many studies have focused dental management in hemophilic patients, however few papers have dealt with oral microflora ${ }^{17,25}$. Candida carriage in these patients could be modified by administration of hemoderivatives or other drugs, and alterations in the immunological system as a consequence of infections, as HBV, HCV and/or HIV ${ }^{4,24}$. The aim of this paper was to quantify Candida in saliva and identify its species in normal and hemophilic patients, considering clinical factors that could influence Candida carriage in the oral cavity.

\section{MATERIALAND METHODS}

A total of 129 patients were studied, 86 with hemophilia from the Hematology and Hemotherapy Center/UNICAMP, and 43 healthy subjects as control. All hemophiliacs were males, with a mean age of 27.5 years (range from 3 to 69 years). They were classified according to hemophilia type (A or B) and severity of the disease. Previous hemorrhagic episodes, blood or hemoderivatives transfusions, serological data, and occurrence of viral infections were considered. Control patients did not have any history of previous or present systemic disease. The male to female ratio was 1.0:0.8 (24/19), with a mean age 29.3 years old (range from 7 to 60 years).
All patients were submitted to physical intraoral examination and collection of unstimulated saliva for $5 \mathrm{~min}$. Salivary flow was classified as reduced $(<0.2 \mathrm{~mL} / \mathrm{min})$, normal ( $>0.3$ and $<0.4 \mathrm{~mL} / \mathrm{min}$ ) and abundant $(>0.5 \mathrm{~mL} / \mathrm{min})$, according to the criteria described by Screebny, et al. ${ }^{23}$ (1989). Salivary samples were cultured in Saboraud dextrose agar with chloramphenicol for 48 hours, and Candida counts were expressed as CFU/ml. According to Candida count, each patient was considered "negative" $(\mathrm{CFU} / \mathrm{mL}=0)$, “carrier” (CFU/mL > 0 or < 400) and "positive" $(\mathrm{CFU} / \mathrm{mL}<$ 400). Candida species identification was performed by germ tube and chlamydospores production, and carbohydrate fermentation and assimilation, according to Sandvén ${ }^{22}$ (1990) and Larone ${ }^{10}$ (1995).

Data were statistically analyzed by t test, chi-square, Wilcoxon, Kruskal-Wallis and two-tailed exact Fischer, using the EPI-INFO 6.04b program (CDC, USA), at a significance level of $5 \%$.

\section{RESULTS}

Twenty-nine (34\%) out of 86 hemophiliacs showed one or more viral infections diagnosed by serological tests (Table 1). Most of the patients with severe hemophilia A presented viral infections, and HCV was the most common, followed by HIV and CMV. Only one patient had HBV, and 8 presented simultaneous infections with two or more virus. Surprisingly no patient with severe Hemophilia B was infected, but 4 out of 8 with mild Hemophilia B were positive for HCV and one for HIV. Twenty-one patients had one viral infection and eight, two or more $(\mathrm{HCV}+\mathrm{HIV}=1, \mathrm{HCV}+\mathrm{CMV}=2, \mathrm{HCV}+$ $\mathrm{HIV}+\mathrm{HBV}=1$, and $\mathrm{HCV}+\mathrm{HIV}+\mathrm{CMV}=4)$. Smoking and drinking habits were higher in the control group, but use of drugs and prosthesis was similar in both groups (Table 2).

Mean salivary flow rates of both groups were statistically different $(\mathrm{p}=0.0025)$, but within the range of normal values, $0.49 \pm 0.11 \mathrm{~mL} / \mathrm{min}$ and $0.41 \pm 0.21 \mathrm{~mL} / \mathrm{min}$ for the control and hemophilic groups, respectively. Nevertheless, in both groups, few patients had reduced salivary flow. Candida

TABLE 1- Distribution of 86 hemophilic patients regarding to type of hemophilia, severity of the disease and viral infections

\begin{tabular}{|c|c|c|c|c|c|}
\hline \multirow[t]{2}{*}{ Hemophilia } & \multicolumn{2}{|c|}{ Viral Infection } & \multirow[b]{2}{*}{ HBV } & \multirow[b]{2}{*}{ CMV } & \multirow[b]{2}{*}{$\begin{array}{c}\text { Two or more } \\
\text { viruses }\end{array}$} \\
\hline & $\mathrm{HCV}$ & HIV & & & \\
\hline \multicolumn{6}{|l|}{ Hemophilia A(68) } \\
\hline Severe $(n=34)$ & $16(61.5 \%)$ & $6(75.0 \%)$ & 0 & $6(86.0 \%)$ & $7(87.5 \%)$ \\
\hline Moderate $(n=18)$ & $3(11.5 \%)$ & 0 & 0 & $1(14.0 \%)$ & 0 \\
\hline Mild $(n=16)$ & $2(8.0 \%)$ & $1(12.5 \%)$ & $1(100 \%)$ & 0 & $1(12.5 \%)$ \\
\hline \multicolumn{6}{|l|}{ Hemophilia B(18) } \\
\hline Severe $(n=5)$ & 0 & 0 & 0 & 0 & 0 \\
\hline Moderate $(n=5)$ & $1(4.0 \%)$ & 0 & 0 & 0 & 0 \\
\hline Mild $(\mathrm{n}=8)$ & $4(15.0 \%)$ & $1(12.5 \%)$ & 0 & 0 & 0 \\
\hline Total $(n=86)$ & $26(30.23 \%)$ & $8(9.3 \%)$ & $1(1.16 \%)$ & $7(8.13 \%)$ & $8(9.3 \%)$ \\
\hline
\end{tabular}


was not detected in saliva of 56\% of control patients, and $36 \%$ of the hemophiliacs. On the other hand, $42 \%$ of the hemophiliacs were considered positive, but only $28 \%$ of the controls. Type and severity of hemophilia did not influence the presence of Candida in saliva (Table 3).

About $73 \%$ of the HCV-positive patients and $87.5 \%$ of the HIV-positive patients were Candida carriers/positive in saliva. To assess the influence of these viral infections on Candida carriage in saliva, patients affected by each of the infections (HIV, HCV, HBV, and CMV) were excluded and Candida carriage was analyzed in the remaining individuals. Results showed no statistically significant differences between groups and in the hemophilic group as a whole. On the other hand, when considering only hemophiliacs with viral infections, they carried more Candida in saliva when compared to control and hemophilic group without viral infections (Table 4). The influence from complete dentures and salivary flow on salivary Candida carriage in hemophilic patients was also analyzed, and exclusion of one or both of these factors did not interfere with Candida counts (Table 5).
Regarding Candida species, C. albicans corresponded to 68 and 65\%, C. tropicalis 37 and 51\%, and Candida sp 26 and $9 \%$ in the control and hemophilic groups, respectively. C. krusei (1 patient) and Rhodotorula rubra (1 patient) were also isolated from hemophiliacs (Table 6).

\section{DISCUSSION}

Hemophilia is a hereditary hemorrhagic disorder, characterized by deficiency in factors VIII or IX, which are fundamental glycoproteins in blood clotting ${ }^{2,26}$. Some primary or secondary hemophilia-related factors, as viral infections and transfusion therapies, can interfere with the immune system and predispose hemophiliacs to alterations in oral microflora and, consequently, to oral infections ${ }^{6,8,21}$.

The present results showed that Candida was more frequently found in the saliva of hemophilic patients (64\%) than in controls (44\%). It was also noticed that, although the frequency of Candida carriers/positives was higher in hemophiliacs, there were no cases of clinical oral candidiasis.

TABLE 2- Distribution of 86 patients and 43 healthy individuals regarding to smoking and drinking habits, complete dentures, and drug use

\begin{tabular}{llll}
\hline Parameter & $\begin{array}{l}\text { Control (43) } \\
\mathbf{n}(\%)\end{array}$ & $\begin{array}{l}\text { Hemophiliacs (86) } \\
\mathbf{n}(\%)\end{array}$ & $\mathrm{p}$ value \\
\hline Smoking & $7(16.3 \%)$ & $3(3.6 \%)$ & $\mathrm{p}=0.015$ \\
Drinking & $4(10.3 \%)$ & $0(0.0 \%)$ & $\mathrm{p}=0.011$ \\
Prosthesis & $1(2.4 \%)$ & $7(8.9 \%)$ & $\mathrm{NS}$ \\
Drugs & $2(4.9 \%)$ & $2(2.4 \%)$ & $\mathrm{NS}$ \\
\hline
\end{tabular}

TABLE 3- Distribution of control and hemophilic patients regarding to salivary Candida carriage

\begin{tabular}{lllll}
\hline Type of hemophilia & \multicolumn{2}{l}{$\begin{array}{l}\text { Salivary Candida carriage } \\
\text { Positive } \\
\left(\mathrm{CFU}^{1} / \mathrm{mL}<400\right)\end{array}$} & $\begin{array}{l}\text { Carrier } \\
(\mathrm{CFU} / \mathrm{mL}>0<400)\end{array}$ & $\begin{array}{l}\text { Negative } \\
(\mathrm{CFU} / \mathrm{mL}=0)\end{array}$ \\
\hline $\begin{array}{llll}\text { Hemophilia A (68) } \\
\text { Severe }(\mathrm{n}=34)\end{array}$ & $16(47 \%)$ & $7(20.5 \%)$ & $11(32.5 \%)$ & $3.899 \pm 2.615$ \\
Moderate $(\mathrm{n}=18)$ & $8(44 \%)$ & $4(22 \%)$ & $6(33 \%)$ & $3.255 \pm 1.806$ \\
Mild $(\mathrm{n}=16)$ & $5(31 \%)$ & $5(31 \%)$ & $6(38 \%)$ & $2.717 \pm 0.832$ \\
Hemophilia B (18) & & & & \\
Severe $(\mathrm{n}=5)$ & $2(40 \%)$ & $2(40 \%)$ & $1(20 \%)$ & $3.723 \pm 2.760$ \\
Moderate $(\mathrm{n}=5)$ & $2(40 \%)$ & $1(20 \%)$ & $2(40 \%)$ & $5.403 \pm 3.719$ \\
Mild $(\mathrm{n}=8)$ & 0 & $3(37 \%)$ & $5(63 \%)$ & $4.633 \pm 2.481$ \\
Total $(\mathrm{n}=86)$ & $33(38.4 \%)$ & $22(25.6 \%)$ & $31(36 \%)$ & $3.653 \pm 2.275$ \\
Control $(\mathrm{n}=43)$ & $12(28 \%)$ & $7(16 \%)$ & $24(56 \%)$ & $2.558 \pm 0.910$ \\
\hline
\end{tabular}

$1 \mathrm{CFU}$ - colony forming units in $\log _{10} / \mathrm{mL}$ 
Patients affected by severe hemophilia A or B need more frequent transfusional therapies and could be more susceptible to infections ${ }^{8,13}$. However, in the present patients, severity of hemophilia did not correlate with Candida counts in saliva, indicating that transfusions did not significantly impair immune defense to Candida.

Reduced salivary flow has been considered the most important factor leading to Candida carriage and development of candidosis ${ }^{7,15,19}$. In the present study, the mean salivary flow rates of both groups, although different, were within normal range. Therefore the increased salivary Candida carriage in hemophiliacs cannot be explained simply considering salivary flow.

Several systemic factors have been related to oral candidiasis, such as immunosuppression, HIV and other viral infections ${ }^{3,4,16,27}$. From 86 hemophilic patients, 8 were HIV-positive, and of these, 7 were Candida carriers/positives in saliva. All 8 patients were using anti-retroviral therapies without clinical disease. It is well known that HIV is an important factor for Candida colonization of the oral cavity $^{18,28}$. HCV and CMV infections did not influence salivary Candida carriage. In the present sample, only one HBV patient was positive to salivary Candida. When only individuals with viral infections were analyzed, about 73\% of hemophiliacs were Candida carriers/positive in saliva. This clearly indicates that other infections are positively related to the presence of Candida in the mouth. Nevertheless, the relatively small number of patients studied

TABLE 4- Influence of viral infection in salivary Candida carriage in hemophiliacs with and without viral infections and control group

\begin{tabular}{llll}
\hline Group & $\begin{array}{l}\text { Positive } \\
(\mathrm{CFU} / \mathrm{mL}<400)\end{array}$ & $\begin{array}{l}\text { Carrier } \\
(\mathrm{CFU} / \mathrm{mL}>0<400)\end{array}$ & $\begin{array}{l}\text { Negative } \\
(\mathrm{CFU} / \mathrm{mL}=0)\end{array}$ \\
\hline Hemophiliacs with viral infections $(\mathrm{n}=29)$ & $15(51.7 \%)$ & $6(20.6 \%)$ & $8(27.5 \%)$ \\
Hemophiliacs without viral infections $(\mathrm{n}=57)$ & $21(37 \%)$ & $13(23 \%)$ & $23(40 \%)$ \\
Total $(\mathrm{n}=86)$ & $33(38.4 \%)$ & $22(25.6 \%)$ & $31(36 \%)$ \\
Control $(\mathrm{n}=43)$ & $12(28 \%)$ & $7(16 \%)$ & $24(56 \%)$ \\
\hline
\end{tabular}

TABLE 5- Influence of oral prosthesis (complete dentures) and reduced salivary flow in salivary Candida carriage in hemophilic patients

\begin{tabular}{llll}
\hline Parameters & \multicolumn{2}{l}{ Salivary Candida carriage } & Carrier \\
& $\begin{array}{l}\text { Positive } \\
(\mathrm{CFU} / \mathrm{mL}<400)\end{array}$ & $\begin{array}{l}\text { Negative } \\
(\mathrm{CFU} / \mathrm{mL}>0<400)\end{array}$ & $(\mathrm{CFU} / \mathrm{mL}=0)$ \\
\hline All hemophiliacs $(\mathrm{n}=86)$ & $33(38.4 \%)$ & $22(25.6 \%)$ & $31(36 \%)$ \\
Excluding oral prosthesis $(\mathrm{n}=79)$ & $31(39 \%)$ & $18(23 \%)$ & $30(38 \%)$ \\
Excluding reduced salivary flow $(\mathrm{n}=72)$ & $28(39 \%)$ & $18(25 \%)$ & $26(36 \%)$ \\
Excluding both factors above $(\mathrm{n}=52)$ & $20(39 \%)$ & $10(19 \%)$ & $22(42 \%)$ \\
Excluding both factors above and viral infections $(\mathrm{n}=40)$ & $14(35 \%)$ & $7(17.5 \%)$ & $19(47.5 \%)$ \\
\hline
\end{tabular}

TABLE 6- Candida species found in control and hemophilic patients

\begin{tabular}{lll}
\hline Candida species & $\begin{array}{l}\text { Control }(\mathbf{n = 4 3 )} \\
\mathbf{n}(\%)\end{array}$ & $\begin{array}{l}\text { Hemophiliacs }(\mathbf{n}=\mathbf{8 6}) \\
\mathbf{n}(\%)\end{array}$ \\
\hline C. albicans & $13(68 \%)$ & $36(65 \%)$ \\
C. tropicalis & $7(37 \%)$ & $28(51 \%)$ \\
Candida sp & $5(26 \%)$ & $5(9 \%)$ \\
C. krusei & 0 & $1(2 \%)$ \\
Rhodotorula rubra & 0 & $1(2 \%)$ \\
\hline
\end{tabular}


should be considered, and in some cases the viral disease was under control, as in HIV patients.

C. albicans is the most common oral Candida species, representing 60 to $90 \%$ of the isolates in normal and immunocompromised individuals ${ }^{8,20}$. The present results revealed that $C$. albicans and $C$. tropicalis were the most common species in controls and hemophiliacs. When considered the 40 hemophilic patients without any local or systemic factors (viral infections, complete dentures, and salivary flow), 21 were Candida carriers/positives in saliva and, from these, 16 (76\%) were positive for C. albicans and 10 (47\%) for C. tropicalis, showing that former group carried more Candida than the control.

It is interesting to note the high frequency of $C$. tropicalis in patients of both groups, not reflecting the literature data $^{1,11}$. This can be interpreted as a regional higher incidence of $C$. tropicalis in the present population and should be better clarified.

\section{CONCLUSION}

In summary, in the present study, hemophiliacs showed higher salivary Candida counts and higher number of individuals carriers/positives for Candida when compared to controls. Viral infections facilitated the presence of Candida in the mouth, nevertheless hemophiliacs without any viral infections significantly carried more Candida than controls. No factor could be found, inherent or not to hemophilia, that could significantly contribute to the increased salivary Candida counts in these patients, and this deserves further studies.

\section{ACKNOWLEDGEMENTS}

This work was supported by FAPESP and CAPES Brazil.

\section{REFERENCES}

1- Cannon RD, Holmes AR, Mason AB, Monk BC. Oral Candida: clearance, colonization or candidiasis? J Dent Res 1995;74 (5):115161.

2- Chao H, Walsh CE. Hemophilia gene therapy: novel rAAV vectors and RNA repair strategy. Curr Opin Mol Ther 2002;4(5):499-504.

3- Franker CK, Lucartorto FM, Jonhson BS, Jacobson JJ. Characterization of the microflora from oral mucosal surfaces of some HIV-infected patients. Oral Surg Oral Med Oral Pathol 1990; 69(6):683-7.

4- Giangrande PLF. Hepatitis in haemophilia. Br J Haematol 1998;103(1):1-9

5- Hoyer LW. Medical progress: Hemophilia A. N Engl J Med 1994;330(1):38-47.

6- Kekow J, Plendl H, Gross WL. Influence of factor substitution on the B-cell response in hemophiliacs. Cancer Detect Prev 1987;1:43-
7- Khurshudian AV. A pilot study to test the efficacy of oral administration of interferon-alphalozenges to patients with Sjogren's syndrome. Oral Surg Oral Med Oral Pathol Oral Radiol Endod 2003; 95(1):38-44.

8- Kim K-Y, Yang CH, Kang SH. A comprehensive study of immunological abnormalities in Korean hemophiliacs. Yonsei Med J 1989;30(2):180-6

9- Kindelan SA, Yeoman CM, Douglas CW, Franklin C. A comparison of intraoral Candida carriage in Sjögren's syndrome patients with healthy xerostomic controls. Oral Surg Oral Med Oral Pathol Oral Radiol Endod 1998;85(2):162-7.

10- Larone DH. Medically important fungi: a guide to identification. ASM Press, Washigton. Chapter 4: Yeasts and yeastlike organism. 1995;61-89.

11- Leung AYH, Chim CS, Ho PL, Cheng VC, Yuen KY, Lie AK, et al. Candida tropicalis fungemia in adult patients with haematological malignancies: clinical features and risk factors J Hos Infec 2002;50(4):316-9.

12- Manfredi M, McCullough MJ, Al-Karaawi ZM, Hurel SJ, Porter SR. The isolation, identification and molecular analysis of Candida spp. isolated from the oral cavities of patients with diabetes mellitus. Oral Microbiol Immunol 2002;17(3):181.

13- Mannucci PM. Ham-wasserman lecture: hemophilia and related bleeding disorders: a story of dismay and success. Hematology (Am Soc Hematol Educ Program), 2002. p.1-9.

14- Mannucci PM, Tuddenham EGD. Medical progress: The hemophilias - from royal genes to gene therapy. N Engl J Med 2001;344(23):1773-9.

15- Navazesh M, Christensen C, Brightman VJ. Clinical criteria for the diagnosis of salivary gland hypofunction. J Dent Res 1992;71(7):1363-9.

16- Nikawa H, Jin C, Makihira S, Egusa H, Hamada T, Kumagai H. Susceptibility of Candida albicans isolates from the oral cavities of HIV-positive patients to histatin-5. J Prosthet Dent 2002; 88(3):263-

17- Okuda K, Yamanaka A, Kubodera T, Ikeda M, Takozoe I. A study of the subgingival microflora of HIV-seropositive and CD4 cell depleted children with hemophilia. Bull Tokyo Dent Coll 1994; 35(2):91-4.

18- Philip CF. Saliva and salivary gland alterations in HIV infections. J Am Dent Assoc 2001; 122: 122-46.

19- Pires FR, Santos EB, Bonan PR, Lopes MA, Almeida OP. Denture stomatitis and salivary Candida in Brazilian edentulous patients. J Oral Rehabil 2002; 29(11):1115-9.

20- Reichart PA, Samaranayake LP, Samaranayake YH, Grote M, Pow E, Cheung B. High oral prevalence of Candida krusei in leprosy patients in Northern Thailand. J Clin Microbiol 2002; 40(12):447985.

21- Roy KM, Bagg J, Follett EA, Brewer A, Lowe GD. Hepatitis C virus in saliva of haemophiliac patients attending an oral surgery unit. Br J Oral Maxillofac Surg 1994;34 (2):162-5.

22- Sandvén P. Laboratory identification and sensitivity testing of yeast isolates. Acta Odontol Scand 1990; 48(1):27-36.

23- Screebny LM, Valdini A, Yu A. Xerostomia. Part II: Relationship to non oral symptoms, drugs and disease. Oral Surg Oral Med Oral Pathol 1989; 6 (4) 419427. 
24- Shimizu S, Chen K-R, Tagami H, Hanabusa H. Mucocutaneous manifestation in Japanese HIV-positive hemophiliacs. Dermatology $2000201321-5$.

25- Sonbol D, Pelargidou M, Lucas VS, Gelbier MJ, Mason C, Roberts GJ. Dental health index and caries-relates microflora in children with severe haemophilia. Haemophilia 2001;7:468-74.

26- Soucie MJ, Nuss R, Evatt B, Abdelhak A, Cowan L, Hill H, et al Mortality among males with hemophilia: relations with source of medical care. Blood 2000;96(2):437-42

27- Teanpaisan R, Nittayananta W. Prevalence of Candida species in AIDS patients and HIV-free subjects in Thailand. J Oral Pathol Med $1998 ; 27(1): 4-7$

28- Wray D, Felix DH, Cumming CG. Alteration of humoral responses to Candida in HIV infection. Br Dent J 1990; 168(8):326-9.

29. Xu J, Mitchell TG. Geographical differences in human oral yeast flora. Clin Infec Dis 2003;36:221-4. 